\title{
Exploring EFL learner autonomy in the 2013 Curriculum implementation
}

\author{
Sa'adah Ramadhiyah ${ }^{1}$ and Nenden Sri Lengkanawati ${ }^{2}$ \\ ${ }^{1}$ Department of English Education, Faculty of Language and Literature Education, Universitas Pendidikan Indonesia, \\ Jl. Dr. Setiabudhi No. 229 Bandung, West Java, Indonesia
}

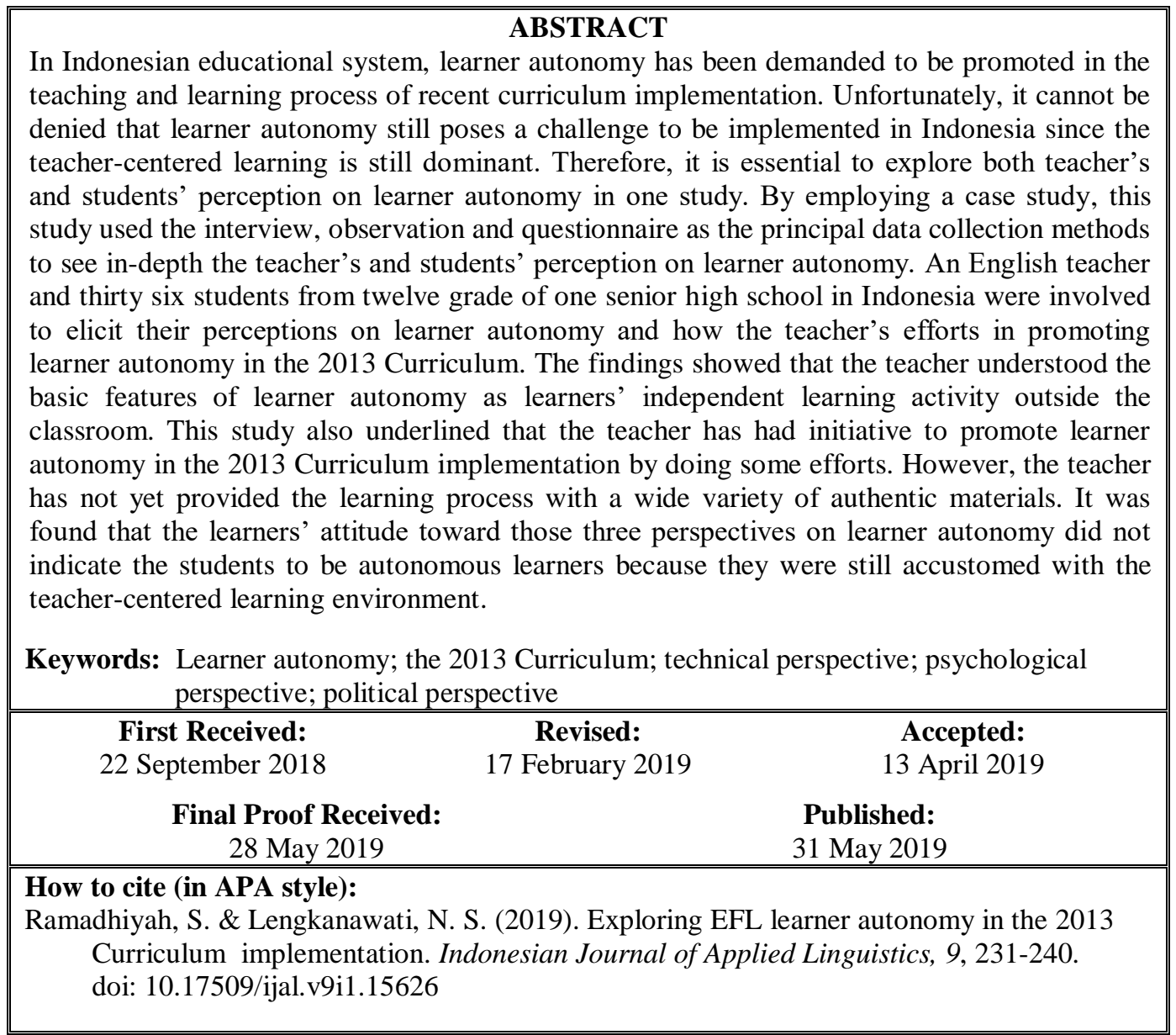

\section{INTRODUCTION}

Since the issue of learner autonomy has been more significant in educational circles nowadays, the Indonesian government has made a move in recent curriculum to demand the teachers to promote learnercentered (learner autonomy) in the teaching and learning process. It is explicitly stated in the regulation of 2013 Curriculum of Indonesia that the teachers should move on from teacher-centered to learnercentered learning.

However, it cannot be denied that learner autonomy still poses a challenge to be implemented in Indonesia because of some issues. Learner autonomy may work very well in western contexts but not in
Indonesian contexts because of the standard norm in the Indonesian culture in learning such as the principles of total obedience, the unquestioning mind, the concept of elders-know-all, and the belief that teachers can do no wrong (Dardjowidjojo, 2001). Another reason is, unlike in western context, Indonesia educational setting mostly has big classrooms which involve more than 25 students in a classroom.

Moreover, some teachers feel that it is hard to trigger some students to take part and initiate on their own learning during the teaching and learning process. It is due to the attitude of self-directed learning that does not normally happen in most schools in Indonesia. In addition to that most students in Indonesia have been

\footnotetext{
* Corresponding Author

Email: saadah.ramadhiyah@gmail.com
} 
raised in a condition of being recipients in learning. They also mostly rely on teachers for what to learn and how to learn. As the result, the students frequently cannot see their needs in studying English and many of them tend to be less eager and enthusiastic to take the chance in learning English (Padmadewi, 2016). Those issues seem to be the reasons that learner autonomy is rarely implemented in Indonesian classroom. However, the teachers have no choice to neglect the demand made in the 2013 Curriculum implementation that suggest them to promote learner autonomy in their classroom.

Little (1999) explains the basis of learner autonomy as the acceptance of responsibility for one's own learning; the development of learner autonomy depends on the exercise of that responsibility in a neverending effort to understand what one is learning, why one is learning, how one is learning, and with what degree of success. In other words, Holec (1981, as cited in Cotterall, 2000) confirms that learner autonomy deals with the responsibility for determining the purpose, content, rhythm, and method of their learning, monitoring its progress, and evaluating its outcomes. Learner autonomy refers to the ability of the learner to take charge of one's own learning by making himself capable of making his own decision in determining learning objectives, defining the contents and his progress, selecting methods and techniques, monitoring the procedures of acquisition, and evaluating what has been acquired (Lengkanawati, 2017).

Some previous researchers in Indonesia (Agustina, 2017; Ja, 2017; Meysani \& Rambet, 2017) have found that the teachers have had positive perspectives toward learner autonomy, the findings reveal that the teachers believed and suggested that preparing activities that promoted language learner autonomy are essential for English learning and the teachers got important roles in promoting learner autonomy to the students. It means most of English teachers in Indonesia have got willingness to promote learner autonomy in the teaching and learning process. The other study conducted by Kemala (2016), she found out that autonomous learners are influenced by mostly learners' desire themselves, and then it was followed by environment, learning tasks, teachers and materials. Most of high autonomous learners were triggered in learning English because of their needs to get their career in the future and due to others aspects.

Even though the research findings that have been mentioned above imply that the teachers have got positive perspectives of learner autonomy, learner autonomy is still less implemented in Indonesia although the 2013 Curriculum requires learner autonomy in the learning process. Besides, the studies of learner autonomy in Indonesian context seem to focus mostly on teachers' perspective. As the result, learners' perspective of learner autonomy in the Indonesian context is still left less noticed. Meanwhile, Harmer (2007) said that when encouraging students to be autonomous learners, both teachers and students should treat learner autonomy in the same way. That is why both perspectives of teachers and students should be recognized.

Therefore, to fill this gap, the present study explored EFL learner autonomy in the 2013 Curriculum implementation by investigating both teacher's and students' perspective of learner autonomy in one study and how teacher attempts to promote learner autonomy in the 2013 Curriculum implementation.

\section{METHOD}

This study employed a qualitative research, specifically using a case study research design to answer the statements of the problem above-mentioned. A case study is the strategy to answer 'how' or 'why' research questions which focus on a contemporary phenomenon within some real-life context (Yin, 2009). This research attempted to obtain in-depth information about EFL learner autonomy in the 2013 Curriculum implementation which particularly investigated how the teacher and the students perceive learner autonomy and how the teacher attempts to promote learner autonomy in her classroom. The case being investigated in this study was EFL learner autonomy in the 2013 Curriculum implementation.

\section{Research site and participants}

As the aim of this study was to find out EFL learner autonomy in the 2013 Curriculum implementation, this study was conducted in one of senior high school in West Sumatra, Indonesia. This school was selected purposively because this school has been implementing the 2013 Curriculum since the first time the government decided the regulation to implement it. This study involved one teacher and her 36 students. The teacher was selected purposively based on some considerations. Firstly, she has teaching experiences for more than fifteen years. Secondly, she has some knowledge about the 2013 Curriculum and its implementation since she is the target teacher of the 2013 Curriculum training. It ensures that she has sufficient familiarity with the 2013 Curriculum implementation. Thirdly, she is a certified teacher who has been supervised by the principle and the assessor to confirm she is professional in teaching. Fourthly this teacher was allowed by the principle to participate in this research since sometimes the researcher needed her time to participate in interviews and observations. Lastly, she agreed to participate in the entire research process and give valuable information to answer the research questions in this study. Besides, the science class was selected purposively by the researcher after getting observation first in all the twelve grade classes in that school. Based on the preliminary observation, the students in this class were more active rather than the students in other classes. There were seven male students and twenty nine female students.

\section{Instruments}

In obtaining the data for exploring EFL learner autonomy in the 2013 Curriculum implementation, this study was conducted by using some instruments; 
classroom observation, interview and questionnaire. According to Creswell (2008), the varied qualitative data are placed into observations, interviews, questionnaires, documents and audio-visual materials.

Classroom observation was conducted to gain specific information about how teacher attempts to promote learner autonomy in learning English as a foreign language in the 2013 Curriculum implementation. During the observation, the researcher acted as a non-participant observer. In other words, the researcher just sat at the back of the class without interfering the teaching and learning process and took field notes about the situation in the classroom such as what teacher did and what the students did. By being a non-participant observer, the researcher was able to get the natural situation of the teaching and learning process as required for the case study data.

Moreover, within the consent from the teacher and the students, the researcher video-taped the learning process and learning activities for the rest of teaching and learning by using video recorder in order not to miss each activity. One observation was conducted for each meeting as the teacher taught in her classroom in length 90 minutes on average. Besides that, in doing the observation, the researcher also used the observation checklist which was organized from the theories of an autonomous classroom by Dam (2008), Littlewood (1996) and Thanasoulas (2000).

The other research instrument for collecting the data was done by using a semi-structured interview. It was conducted to obtain more information about the teacher's perception of learner autonomy and how the teacher promoted it in the classroom. The teacher was interviewed by using some questions modified from interview guidelines of learner autonomy (Borg \& AlBusaidi, 2012). The interview itself was categorized into five components; the teacher's knowledge on learner autonomy, the teacher's root of her current view in learner autonomy, the teacher's view on desirability and feasibility on learner autonomy in the classroom, and the teacher's effort to promote learner autonomy in the 2013 Curriculum implementation.

The questionnaire was also used in order to find out the answer of the first research question which investigated the students' perception in learner autonomy based on the perspectives from Benson (2001) included technical, psychological and political perspectives by exploring their learning behaviour. The questionnaire was modified by the researcher based on the previous studies in the same field (Farahani, 2013; Tamer, 2013; Chan, 2001) which also investigated students' perspectives on learner autonomy. This questionnaire involved 53 items including 24 items for technical perspectives, 11 items for psychological perspectives, 10 items for political perspectives. It was shared to the students in Bahasa Indonesia to make them easier to understand the items of questionnaire.

\section{Procedure of collecting the data}

In order to obtain the data for the research, there were some research procedures taken by the researcher. Since actually, the researcher has asked for the teacher's consent to participate in this research a month before this collected data administered, the researcher still needed to ask for the ethical permission to the school and made sure to the teacher's availability to be the participant for this research. The researcher explained to the teacher and the principal about the data needed, the students' participation was needed in this research and the length of data collected in that school. The teacher's lesson plan was also asked by the researcher to the teacher in order to enrich the observation data on the teaching and learning process in the 2013 Curriculum implementation.

The collecting data was done for a month including four meetings of observations, one session of interview with teacher and one meeting for sharing questionnaire to the students. Before observing the teacher's teaching activities in the classroom to find out how she attempted to foster learner autonomy in the classroom, the researcher prepared observation checklist, notes and video recorder which allowed her to record the entire learning process. After some observations were carried out to find out the learning process in the teacher's teaching practice, the information of the teacher's perspective on learner autonomy was further gained through the interview. Then, in order to make sure the interview ran well, the researcher firstly informed about what was going to be discussed along with the interview. The interview was conducted in Bahasa Indonesia since it was first confirmed to the teacher the language she preferred to be used during the interview. The researcher also recorded the interview by firstly asking for the teacher's consent to be recorded during the interview session.

Moreover, the questionnaire was shared to each student after all learning activities planned by the teacher had been done in order not to disturb teaching and learning process. Firstly, the researcher explained to the students about the questionnaire and making them sure that this questionnaire had no relationship with their English grade in the end of the semester. It was also explained how they should fulfil that questionnaire and suggested them to ask questions to the researcher when they found something they did not understand in the questionnaire. The students spend less than 20 minutes to fulfil the questionnaire.

\section{Data analysis}

The classroom observation was used to investigate how the teacher attempted to create an autonomous classroom in the 2013 Curriculum implementation and how the students acted as the autonomous learners. The observation data taken from videotaping and field notes in the observation checklist were analyzed and categorized referring to the theories of an autonomous classroom and fostering learner autonomy in the classroom from Dam (2008), Littlewood (1996) and Thanasoulas (2000) in order to see the suitable with the theories. 
Moreover, the data obtained from the interview were analyzed by transforming it into transcription and coding it to be organized based on the categories or themes from Borg and Al-Busaidi (2012). According to Creswell (2008), the interview data were analyzed by organizing and preparing the data, reading all the data, coding the data, generating those data into categories or themes, planning on data description and finally writing a qualitative interpretation. The data from the interview were first gathered into the interview, and then the data were translated into English. After organizing the data into transcription form, some important notes were taken in order to code them into several themes and categories. The data were presented in the form of the participant's interview excerpt to give an explanation for analysis.

The collected data from the questionnaire were analyzed by using descriptive statistics which knowing the general result into percentile rank, to find out the perspective of students in learner autonomy. Besides, analyzing the questionnaire in a qualitative study is done by indicating the percentage of responders who selected each alternative for each item in the questionnaire (Gay \& Airasian, 2000). The responses of the questionnaire in each item were analyzed manually and also by using Microsoft Excel to find out the quantity of each item and transformed into percentile rank. Then, the results were interpreted into qualitative narration.

\section{FINDINGS AND DISCUSSION}

To provide a clear presentation of the findings, the research findings on learner autonomy are discussed according to both of their theoretical and practical implications under the following main headings: 1) how do the students perceive learner autonomy? 2) How does the teacher perceive learner autonomy? and 3) how does she attempt to promote learner autonomy in the 2013 Curriculum implementation?.

\section{Learners' perspectives of learner autonomy}

The first research finding is about the learners' perspectives in learner autonomy. This finding was based on the data gathered by using a questionnaire. The learners' perspectives in learner autonomy are divided into three perspectives; technical perspectives which deal with learning activities and learning strategies of learners; psychological perspectives which deal with the learners' self-confidence toward their ability to be an autonomous learner; and political perspectives which include the learners' perspective on their empowerment and freedom to manage their own learning. The findings of the three perspectives will be further explained below.

\section{Technical perspectives}

Technical perspectives involve the students' learning activities and learning strategies which make them autonomous learners. Regarding to the technical perspectives, the finding confirmed that the students did not indicate that they were autonomous learners technically. It means from all the learning activities and strategies which categorized them as autonomous learners, most of the students just did those activities sometimes. It was found that not more than $10 \%$ of the respondents who indicated to do those activities frequently to improve their English learning.

For instance, in research finding, it reveals that there were $63.9 \%$ of the students who rarely did assignment which were not compulsory, $5.6 \%$ of them never did that. It means they just did the assignment which was obligated to them. They just did the tasks given by their teacher in order to be graded. Some students might initiate to do the tasks when they were required to do that or when they had examination. In other words, they learned English because they need grade, not the skill. It is in line with the result in previous study that students' motivation in learning English in Indonesia seems to be practical in the sense that their motivation is based on their immediate needs (Bradford, 2007).

In terms of managing their learning, based on the result, there was no student who frequently gave suggestion or comments to their teacher about the learning. There were $30 \%$ of them who sometimes gave suggestion to their teacher related to the teaching and learning process. It indicates that they just received everything the teacher gave to them. Suryanto (2014) mentions that Indonesian cultural learning which is mostly teacher-centered learning makes the students rarely respond to the teacher by critically arguing what the teachers deliver in front of the class. It could be the reason why the students barely took chance to involve in managing their own learning.

However, when it comes to the learning activities which are integrated to the technology such as listening to English songs, watching English movies, and watching English TV programs and YouTube channel, there were more than $50 \%$ of the students who often did those learning strategies. It indicates that the students tended to have the learning strategies which gave them opportunity to observe the authentic materials and it was also integrated with the technology. It is in line with Lamb's (2013) research result that In Indonesia, which the teaching and learning process depends on the textbooks, assessments and the professionalism of their class teacher, globalization and its technologies are having the effect of increasing the desire for English among young people and providing the innovative means of accessing it.

In this globalization era, everyone can easily get access with the internet through their computer and smartphone. The students might be claimed to have common in technology. As it is said by Acevedo (2016) that the presence of technology in society is significant, it can be said that nowadays citizens live in a technology mediated society. It is relevant with the research finding that the students tended to do some independent learning strategies which integrated with the technology rather than the others learning strategies. 
One of the previous studies proved that the use of technology was beneficial for students' engagement and could be set as a resource of learner autonomy (Prensky, 2001). The other reason that influenced the students' initiative in learning might be their enthusiasm into the innovation of technology devices in this globalization era. It might not be interested to the students if it was not something new for them, like they had lack of interest in reading the textbooks because they have done it frequently in classroom with their teacher. It was one said that the novelty effect must be noted as students' enthusiasm for getting to use a technology device in education, it might decrease when the technology is no longer a new sensation (Punie, Zinnbauer, \& Cabrera, 2006).

Furthermore, this finding also related to the regulation of the 2013 Curriculum. In the 2013 Curriculum, the scientific approach is decided to be the learning approach to be used. One of the learning stages in scientific approach is observing. In this stage, the students have a chance to observe something from the pictures, videos, audios, or the teachers' story which related to the learning topics. In this case, the students are stimulated to give some questions about the learning topics and even guess the learning topics that will be discussed in the classroom. That is why, from the findings, it shows that the students tended to have interest with the learning materials which integrated with the technology, because they got stimulation to the target language as it usually happened in the observing stage.

Regarding to the observing in the 2013 Curriculum implementation, there are two main activities that should be done to lead to the observing steps (Zaim, 2017). First, the teacher gives the students a wide opportunity to do observation. The observation can be done through reading, listening, or seeing the object. Second, the teacher facilitates the students to do observation and train the students to observe the important things from the object. It can be noted that the regulation of the government in the 2013 Curriculum to use the scientific approach as the teaching methodology is regarded to the students' need and interest nowadays. They preferred to observe something independently, particularly something authentic and novelty around them. Besides, the 2013 Curriculum also suggests the teachers to use technology integration in the teaching and learning process (Kemendikbud, 2013). It reveals that the learning strategies done by the students in political perspectives were in line with the aspects of the 2013 Curriculum which involved observing the authentic materials they find around them and it has been integrated with the technology.

\section{Psychological perspectives}

This part indicates the students' perspectives on their ability and skill in some aspects of learner autonomy. In this perspective, the students were investigated to give their perspectives on their ability towards some aspects of learner autonomy. In most items of the questionnaire, the result showed that they thought they were capable in controlling their learning, such as in deciding the materials and learning activities to be used inside the classroom or they used by their own outside the classroom. Even though in these aspects the students perceived their skills were not good or very good, they were confident enough to say they could do those aspects. Littlewood (1996) argues that confidence and motivation should be presented together with students' ability and skills in order for the students to become autonomous. However, in reality, that confidence, motivation and skills were not coming together in the learner's perspectives, that is why; learner autonomy did not take place well in the 2013 Curriculum implementation. In addition to that, psychological perspectives related to the political perspectives which will be currently discussed.

\section{Political perspectives}

The result in political perspectives deals with the students' perspectives in their empowerment and responsibility to manage and participate more in their English learning. The findings in psychological perspectives confirmed that the students felt they were good enough in controlling their own learning independently. On the contrary, in political perspective, it was found that most students perceived the aspects of controlling learning in learner autonomy as the responsibility of their teacher, some of them argued that as both the teacher's and the student's responsibility. Meanwhile, political perspectives emphasize empowerment or emancipation of learners by giving them control over the content and processes of their learning. It is not in line with a theory from Borg and Al-Busaidi (2012) that confirm political perspective focuses on issues of power and control which learners take in managing the content of their learning, for instance, in deciding learning material, evaluating their learning achievement, knowing their learning progress, etc. Political perspective deals with learners' freedom to take control over their own learning, such as determining their learning goals and purposes. In fact, the students still perceived the content of learning as their teacher's responsibility, any other way they were expected to take this responsibility by their own if they want to be autonomous learners.

Otherwise, political perspective of learner autonomy was not perceived by Indonesian students as the perception of western students, because of the culture of the learning system in Indonesia which focus on teacher-centered. As explained by Dardjowidjojo (2001), learner autonomy is not easy to be implemented in the Indonesian context as well as in western context. The social and ethical value in Indonesian context has belief that teachers are knowledgeable person that is why the students obey whatever the teachers ask to do in the class. Furthermore, the existing norm in Indonesia demands that young generation should respect the elderly by not putting them in a shameful condition. It seems to be the reason why the students were still hard 
to put more responsibilities in learning on their hands.

The responsibilities which should be taken by the students to be autonomous learners are the tasks to manage their own learning, even give suggestion to the teacher and decide the learning included the materials, activities and learning goals. This might be hard for the students to give their voices and become critical about the decision in the teaching and learning process. Consequently, this norm made the students dependent to their teacher. It was common for them to be the recipients in learning rather than take part in learning decisions which they usually know as teacher's responsibility. In line with this issue, Suryanto (2014) also mentions that Indonesian students tend to avoid conflicts since they prefer a harmonious condition as part of Indonesian cultures that tend to emphasize on communal life, harmony, sharing and face supporting instead of holding liberalism and individualism as what happened in the western context.

Since this matter might be caused by the norm having by the Indonesian students, it cannot be justified that what they did was worse than the western students, because norms or rules formulate someone's belief and shape someone's behavior over something. However, it is also not impossible to expect the Indonesian students to become autonomous learners, the teacher and the educational stakeholders can work together to train them to be autonomous, but it does not mean they can be compared with the students in the western context because they have different norms, culture and values in learning.

\section{Teacher's perspective of learner autonomy}

There are some points to be highlighted in the research findings of teachers' perspectives on learner autonomy. It includes teacher's knowledge on learner autonomy, teacher's root of the view on learner autonomy, teacher's view on desirability and feasibility on learner autonomy and teacher's effort to promote learner autonomy in her classroom.

First, the teacher perceived learner autonomy mostly happened outside the classroom. She believed that learner autonomy was when learners followed instruction in the classroom and doing each activity which was set by the teacher. As it is seen in the excerpt below:

"Well, learner autonomy. It is the learning activity which is done by the students independently outside the classroom, isn't it? ...We can say it is learner autonomy when the students do their entire task which teacher gives by their own. That's learner autonomy or independent learning. So, after a teacher delivers all learning material and make sure they understand about it, letting them do the task given is kind of independent learning. That is how we define learner autonomy because learners do the task given by their teacher by their own "(Teacher's interview, 24/7/2018).

It indicates that the teacher's perspective of learner autonomy still focused on the teacher-centered. Meanwhile, learner autonomy expects also the students' opportunity to take parts in their own learning such as deciding the learning goals, learning activities, and deciding the materials they want to use in the learning process. It is explained by Little (1991) that learner autonomy depends on the development and exercise of a capacity for detachment, critical reflection, decision making, and independent action by the learners. It means the teacher was supposed to know that learner autonomy was more about the learners' action to take control over their own learning rather than waiting for the teacher's action to force them to do that. Meanwhile, in this case, the teacher perceived learner autonomy as the students' willingness to follow her instruction which means still giving the picture of teacher-centered.

The second result is the teacher's root of view on learner autonomy. The teacher admitted that she had never discussed learner autonomy in the teachers' association (MGMP) with the other teachers and the instructors. It was caused by MGMP in her city was not running really well as it should be. However, she had got the explanation about learner autonomy in the 2013 Curriculum training and the teacher training which were administered by the government. It is noticeable that changing a pedagogical strategy for autonomy in teaching must not be easy for the teacher since the teacher has to move on from her current way of teaching which is in a teacher-centered was to a more learnercentered way. Meanwhile, she did not get enough stimulation to encourage her to moving on from the teacher-centered learning. It can be shown in the excerpt below:

"Teachers should have got it. Unfortunately, since $M G M P$ is not running really well here, that's why we haven't discussed it yet. However, in 2013 Curriculum training or teacher's training, learner autonomy and independent learning are well discussed that independent learning should take place in the classroom. Actually, independent learning and learner autonomy have been familiar also in the previous curriculum, KTSP. However, in 2013 Curriculum, learner autonomy is suggested explicitly"(Teacher's interview, 24/7/2018).

Changing the perspectives and the strategies must be followed by support from the teacher professional development. Even though the teacher could find the information from some literature sources which explain about the strategies of implementing learner autonomy in the classroom, getting discussion through professional development program must give her meaningful insight over her teaching practice in the classroom. Benson (2001) confirms that the assumption behind the professional development project is the introduction of a single strategy in pedagogical practice; it could also make a significant difference to teacher's teaching practice because the strategies are applied comprehensively. That is why the teacher implied that she should have got more training and discussion about learner autonomy in the teacher training program.

In addition with that, the researcher also found about the teacher's view on feasibility and desirability 
of promoting learner autonomy in the classroom. According to the teacher, learners could decide learning materials to be used in the classroom; they also could choose learning activities for the rest of the teaching and learning process as long as they choose it wisely. However, sometimes learners only chose the materials and activities which were fun for them, such as games, watching videos and listening to the songs. In this case, it can be noted that the teacher had less confidence over her own students to be independent learner. Meanwhile, letting learners decide the learning material which they use includes in their self-instruction in learning. Selfinstruction refers to the used of printed or broadcast self-study materials. In a broader sense, it refers to situations in which learners undertake language study largely or entirely without the aid of teachers (Benson, 2007). It is noted that self-instruction will train students' creativity in developing their own learning material which relates to their needs and interest. It is stated in the excerpt below:

"As long as they can do that and what they choose makes sense. I would say, they can choose learning material and learning activities if what they choose and decide should be really useful for their learning. You know, sometimes students only choose what they think it is fun for them, such as games, watching videos, listening to the songs, something like that. They rarely choose like the text to be read in the classroom or the book to be used. However, as long as their suggestion and their choices can be used effectively, why not? Unfortunately, I still cannot find they do that. They still give it all to me." (Teacher's interview, 24/7/2018).

It does not mean that the teacher did something wrong. As the teacher mentioned that she just wanted her students got the effective learning and achieved the learning objectives even if the teaching and learning process became more teacher-centered. Teachercentered learning actually guides learners to stay in line. Cunningham (2008) claims that teacher-centered learning gives the students direction and close supervision in order to maximize their learning; because the amount of instructional and engaged time should be maximized; classrooms should be structured in such a way that the teacher is in control; and appropriate questioning techniques should be employed. Unfortunately, it also cannot be denied that teachercentered learning might block students' creativity in expressing themselves. It is relevant with a theory that said teacher-centered instruction does not allow students to express themselves, ask questions and direct their own learning. Teacher-centered teaching mode suppresses the students' passion and initiative (Gao, 2013).

It seemed difficult for the teacher to let learners decide what they wanted in their learning because she was afraid the learning goal which was regulated by the curriculum could not be achieved. It indicates that the teacher was less feasible to allow the students to participate in making decisions related to curricular goals and assessment. Loi (2016) says that this perception is possibly due to the teacher's lack of autonomy, their confidence in their students' ability, and the context which imposed a top-down curriculum. That is why; learner autonomy still cannot run well in her classroom even if the teacher has positive perspective that learner autonomy is important for the students' learning. However, the teachers' positive perceptions about learner autonomy were not enough to sustain the implementation of learner autonomy in practice when they are doubt about its feasibility. It shows a lack of consistency between her beliefs and her practices. Teacher had conflicting beliefs about whether to follow the entire curriculum or not.

On the other hand, it cannot be said that the teacher had no effort to promote learner autonomy in her classroom. As indicated in findings, the teachers perceived her role to make learner autonomy happened in her classroom by identifying her ways to promote it. She thought she could facilitate the learners with some activities to stimulate them in order to be active in the teaching and learning process. Some activities that she had applied in her classroom were having discussion, analyzing the text together with the students, and also having some games in learning process. It means the teacher had done some efforts to foster her learners to be autonomous learners which proposed by Benson (2003) into five broad guidelines as follow; teachers should be actively involved in students' learning, provide options and resources, offer choices and decision-making opportunities, support learners, encourage reflection. Even though the teacher did not administer all of those strategies, yet, at least she was aware that she must try so hard to promote it in her classroom, as she explained in the excerpt below:

"That's our role as a teacher, finding the ways in order to make the students become active and participate in the classroom. Teacher's role is to create active classroom by facilitating them such activities to make them participate more in the learning process, such as discussion, analyzing the text together, and games also" (Teacher's interview, 24/7/2018).

\section{Teacher's effort to promote learner autonomy}

In terms of the teacher's efforts to promote learner autonomy in the 2013 Curriculum implementation, there are some points which should be discussed. The research result revealed that the teacher had done some ways to foster learner autonomy in order to be happening in her classroom. One of the ways was the teacher liked to encourage learners to evaluate their learning on their own by reflecting on their own mistakes they made. Sometimes, the teacher also invited the other students to do such peer-assessment even for individual learners or the whole students in the classroom. It is in line with Benson's (2007) explanation on the way of promoting learner autonomy in the classroom. Some of the strategies asserted by the teacher, such as independent inquiry which means asking the students to find out things for themselves (rather than telling them), it is believed as a basic strategy for the students' involvement. Then self- and 
peer-assessment, it encouraged a sense that learning is being carried out for the students' own benefit, as well as a sense of responsibility and involvement. It indicates that the teacher actually had the willingness to create the students' involvement in learning.

The other interesting strategy applied by the teacher to promote learner autonomy in her classroom is she tried to create the variety of activities during the teaching and learning process. Sometimes teacher invited the students to play the games, yet still integrated with learning materials. In the other times, the teacher allowed learners to have out of class activities even if she gave the students some tasks to be done outside the classroom. It implies that the teacher had done some ways to promote learner autonomy because she created some different activities in her classroom. It is in line with the theory of autonomous classroom that the strategy of creating autonomous classroom is letting learners engage in many different activities (Dam, 2008). Besides, in terms of inviting the students to have some activities outside the class, it allows students to contribute to learning content by bringing in a personally relevant material (Benson, 2003).

Based on the research findings, the teacher also tended to create learning activities which involved learners into discussion, sharing and analyzing. The teacher always made sure that the students participated in the teaching and learning process by inviting their involvement in the discussion session. It is in line with a theory which stated a strategy of promoting learner autonomy, learner autonomy is promoted when teacher involves learners to create good learning activities, which are shared, discussed, analyzed and evaluated with the whole class (Thanasoulas, 2000).

Besides, in the research result, it was indicated that the teacher carried out group work activities in the teaching and learning process. In most learning activities, it was found that the teacher liked to divide the students into small groups. As it is said by Dam (2008), autonomous classroom is taken place if teacher let learners to work collaboratively in small groups. Moreover, having activities in their groups will give learners the opportunity to have cooperation and interaction between the students. They got chance to have a discussion with their friends about learning materials since they work collaboratively to complete the tasks given by their teacher for each group. Benson (2007) claims that encouraging student-student interaction is helpful for promoting learner autonomy because it heightens the involvement of the students. He also mentions that the more students talk to each other, the more personally relevant the content of learning they get.

However, unfortunately, the effort of promoting learner autonomy was not well done by the teacher in terms of the learning sources and materials. Based on the research findings, the teacher did not prepare material from the variety of learning sources. She only used one textbook as her learning sources for the rest of learning; for instance, she took both dialog examples and learning tasks from the same textbooks since the beginning of the lesson. Meanwhile, based on the theory said by Dam (2008) that teacher should use the various material such as various texts, pictures, videos and use the authentic materials such as magazines, newspapers, laptops computers and learning software programs, etc. As the result, in terms of learning material preparation, the teacher seemed to have less effort because she only focused on one textbook which was also handed by the students. It might be the teacher's way to make the teaching and learning process became more effective because both the teacher and the students used the similar learning sources.

\section{CONCLUSIONS AND RECOMMENDATIONS}

Based on the findings and discussion which have been elaborated earlier, there are some points highlighted in this study. First, the teacher perceived leaner autonomy positively; she knew that learner autonomy is helpful for EFL learning. However, the teachers' positive perceptions about learner autonomy were not enough to sustain the implementation of learner autonomy in practice. Otherwise, the teacher was not sure about its feasibility which means she had less confidence to give the students opportunity to take control in their learning. Even though the teacher felt good to let learners make decision in their own learning which included deciding learning goals, materials and learning activities, the teacher thought that learners tended to choose learning material and learning activities which were fun for them only; so that she felt doubt it could be meaningful for the learning process. It shows a lack of consistency between her beliefs and her practices. The teacher had conflicting beliefs about whether to follow the entire curriculum or not, it can be said that she perceived autonomy reflected a misconception that learner autonomy would lead to a reduction of her work in achieving curriculum goals. She also did not have a complete understanding of the definition of learner autonomy itself. That is why it gave impact to her teaching practice in promoting learner autonomy in the classroom.

Second, the teacher has tried to promote learner autonomy even if there were still some components that need to be improved in order to help the teacher in developing learner autonomy implementation in the classroom; one of them was preparing learning material. Moreover, it was found that the teacher did not often provide learning process with technology integration as it is expected in the 2013 Curriculum implementation. In other words, the teacher had lack of creativity in creating learning activity to encourage learners' interest in EFL learning.

Third, it can be said that the students cannot be indicated as the autonomous learner based on their perceptions. It reveals from the findings of their technical, psychological, and political perspectives. The result was not satisfactory as it is expected. In terms of 
technical perspective, the students mostly had interest in learning activity which related to technology integration such as watching English movies, listening to English song and having chat in English through social media. Most of them seemed to make good use of their technology devices to improve their English. In fact, related to psychological and political perspectives, the students still got an impact on teacher-centered learning. Even though the students felt they had capability to take control in their learning, they still gave that responsibility to their teacher. They perceived that psychologically they could take responsibility in their learning. In otherwise, politically; they perceived they still did not have freedom to take responsibility in controlling their own learning. It might be caused by the socio-cultural aspects in the Indonesian context which hold the teacher-centered learning.

In line with the research findings, it is suggested to the teacher who is currently involved in the process of English language learning and teaching needs to be more creative to prepare their learning materials in order to improve meaningful learning in the classroom, it is also better to integrate technology in learning, it also helps to promote learner autonomy in the classroom. Moreover, it is important for teacher to participate in any training, workshop, and conference discussing the issues of learner autonomy in EFL learning. Since the results show that the students' technical, psychological and political perspectives are not as satisfactory as expected, the teacher is suggested to provide learners more opportunity to negotiate with the teacher about the topic, material and the process of the teaching and learning in terms of learning activity, if the teacher thinks that to negotiate the goals of learning is not possible. By giving them more freedom to choose learning material and learning activities based on their interest, it hopefully can improve their autonomy in learning.

Moreover, the educational authorities are highly suggested to provide the sufficient preparation time, adequate facilities, and effective learning environment to the teacher in order to get improvement in their teaching practice. In addition, more practices in trainings or workshops on developing teaching materials, followed by the controlling activities need to be undertaken by the government and school. This will trigger the teacher to further explore learner autonomy in her/his teaching context

The last but not least, since this research is limited by the time in collecting the data, the participants were not involved more teachers and more students. The further studies are recommended to involve more participants including teachers and students to reveal more valid and in-depth analysis of learner autonomy implementation and its influences on students' language learning. Besides, the present study was carried out at senior high school level, it would, therefore, be interesting to learn more about materials adaptation from different levels such as junior high school or university level. Then, since this research explored learner autonomy in EFL learning including all English skills, the further research is suggested to investigate learner autonomy in a more specific English skill, for example, learner autonomy in speaking or reading, in order to get more in-depth findings for a specific context. It is also suggested to involve interview session for the students for investigating students' perspectives in the further research in order to get a more detailed view on students' perception of learner autonomy.

\section{REFERENCES}

(pp. 11-18). New York: Peter Lang.

Acevedo, N. G. (2016). Technology-enhanced-gadgets in the teaching of English as a foreign language to very young learners: Ideas on implementation. Procedia - Social and Behavioral Sciences, 232, 507-513.

Agustina, D. (2017). A complex system of teachers' beliefs and practices in developing learner autonomy in Indonesian junior high school contexts: A mixed-methods study. (Unpublished doctoral thesis). Victoria University of Wellington, New Zealand.

Benson, P. (2001). Teaching and researching autonomy in language learning. London: Longman.

Benson, P. (2003). Learner autonomy in the classroom. In D. Nunan, (Ed.) Practical English language teaching (pp. 289-308). New York: McGraw Hill.

Benson, P. (2007). Autonomy in language the teaching and learning. Language Teaching, 40(1), $21-40$.

Borg, S. \& Al-Busaidi, S. (2012). Learner autonomy: English language teachers' beliefs and practices. London, England: British Council \& University of Leeds.

Bradford, A. (2007). Motivational orientations in underresearched FLL contexts: Findings from Indonesia. RELC Journal, 38, 302-323.

Chan, V. (2001). Readiness for learner autonomy: What do our learners tell us? Teaching in Higher

Education, 6, 505-518. http://dx.doi.org/10.1080/13562510120078045

Cotterall, S. (2000). Promoting learner autonomy through the curriculum: Principles for designing language courses. ELT Journal, 54(2), 109-117.

Creswell, J. W. (2008). Educational research: Planning, conducting, and evaluating quantitative and qualitative research. New Jersey: Pearson Metrill Prentice Hall.

Cunningham, G.K. (2008) University of North Carolina Education Schools: helping or hindering potential teachers? Pope Center Series on Educational Policy, Pope Center for Educational Policy, Raleigh, North Carolina.

Dam, L. (2008). How do we recognize an autonomous classroom?-Revisited. A TESOL symposium learner autonomy: what does the future hold? Virginia, USA.

Dardjowidjojo, S. (2001). Cultural constraints in the implementation of learner autonomy: The case in 
Indonesia. Journal of Southeast Asian Education, 2(2), 309-322.

Farahani, M. (2014). From spoon feeding to selffeeding: Are Iranian EFL learners ready to take charge of their own learning? Electronic Journal of Foreign Language Teaching, 11, 98-115.

Gao, L. (2013). Study on Reform of Public Physical Education Management in Chinese Universities. In E. Qi, J. Shen, \& R. Dou, (Eds.), The 19th International Conference on Industrial Engineering and Engineering Management. Heidelberg: Springer.

Gay, L. R., \& Airasian, P. (2000). Educational research: Competencies for analysis and application. Prentice Hall: New Jersey.

Harmer, J. (2007). The practice of English language teaching. Malaysia: Pearson Education Limited.

Ja, R. (2017). English teachers' roles in promoting learners' learning autonomy in EFL class of public senior high schools of Ende Regency in academic year 2016 / 2017. Journal of Education and Human Development, 6(2), 105-112. https://doi.org/10.15640/jehd.v6n2a11

Kemala, Z. (2016). An analysis of factors influencing the autonomous learners in learning English. ELTIN Journal, 4 (1), 11-20

Kemdikbud. (2013). Peraturan menteri pendidikan dan kebudayaan nomor 81a tahun 2013 tentang implementasi kurikulum 2013. Jakarta: Kemdikbud

Lamb, M. (2013). 'Your mum and dad can't teach you!': Constraints on agency among rural learners of English in Indonesia. Journal of Multilingual and Multicultural Development, 34(1), 14-29. learning: defining the field and effecting change

Lengkanawati, N. S. (2017). Learner autonomy in the Indonesian EFL settings. Indonesian Journal of Applied Linguistics, 6 (2), 222-231. doi: 10.17509/ijal.v6i2.4847

Little, D. (1991). Learner autonomy. Dublin: Authentic Language Learning Resources.

Little, D. (1999). Learner autonomy is more than a
Western cultural construct. In S. Cotterall \& D. Crabbe (Eds.), Learner autonomy in language learning: Defining the field and effecting change (pp. 11-18). Frankfurt: Peter Lang. Littlewood, W. (1996). Autonomy: An anatomy and a framework. System, 24(4), 427-435.

Loi, N. V. (2016). Learner autonomy in Vietnam: Insights from English language teachers' beliefs and practices. In R. Barnard \& J. Li (eds). Language learner autonomy: Teachers' beliefs and practices in Asian contexts. Phnom Pehn: IDP Education (Cambodia) Ltd.

Meisani, D. R., \& Rambet, R. D. (2017). Teachers' beliefs regarding language learner autonomy and practices of project-based education: A case study of an Indonesian EFL teacher. NOBEL: Journal of Literature and Language Teaching, 8(2), 141-149.

Padmadewi, N. N. (2016). Techniques of promoting autonomous learning in the classroom. Journal of Education and Social Sciences, 3, 45-52.

Prensky, M., (2001) Digital natives, digital immigrants Part 2: Do they really think differently? On the Horizon, 9(6) 1-6.

Punie, Y., Zinnbauer, D., \& Cabrera, M. (2006). A review of the impact of ICT on learning. European Commission, Brussels, 6(5), 635-650.

Suryanto. (2014). Issues in teaching English in a cultural context: A case of Indonesia. The Journal of English Literacy Education, 1(2), 75-83.

Tamer, O. (2013). Students' readiness for autonomous learning of English as a foreign language (Unpublished master thesis). University of Sunderland, UK.

Thanasoulas, D. (2000). What is learner autonomy and how can it be fostered? The Internet TESL Journal, $6(11)$.

Yin, R. K. (2009). Case study research design and $\operatorname{method}\left(4^{\text {th }}\right.$ ed.). California: Sage.

Zaim, M. (2017). Implementing scientific approach to teach english at senior high school in Indonesia. Asian Social Science, 13(2), 33-40. 